\title{
PERBEDAAN TINGKAT REFLEKSI DIRI DALAM PEMBELAJARAN MAHASISWA FAKULTAS KEDOKTERAN UNIVERSITAS MALAHAYATI TAHUN 2019
}

\author{
Sri Maria Puji Lestari ${ }^{1}$ \\ ${ }^{1}$ Departemen Ilmu Kedokteran Komunitas Fakultas Kedokteran Universitas Malahayati
}

\begin{abstract}
Differences In Self-Reflection Level In Learning Of Medical Students Of Malahayati University, 2019. Self-reflection is an important part of the activity, including learning in medical education. Medical students of Malahayati University must be able to do self-reflection to be able to evaluate each learning process and determine what steps should be taken to support their success when taking the level of next stage. To find out the difference in the level of self-reflection in the learning of medical students of Malahayati University class of 2015, 2016, 2017 and 2018 in 2019. This type of research is quantitative with descriptive surveys using the Accidental Sampling method. The population is all students of the Faculty of Medicine Malahayati University class of 2015, 2016, 2017 and 2018.Sample of 644 respondents was obtained. The level of self-reflection Medical students of Malahayati University in 2019 mostly had a moderate level there are 363 respondents $(56.37 \%)$, high self-reflection there are 216 respondents $(33.54 \%)$ and low self-reflection there are 65 respondents $(10.09 \%)$. Most of the class of 2015 had a high level of self-reflection $(64.56 \%)$, while in other classes (2016, 2017 and 2018) they had a moderate level of self-reflection. There are some differences in the level of self-reflection in various class, especially class of 2015, but most of the level selfreflection in learning of medical students of Malahayati University in 2019 has a moderate level.
\end{abstract}

Keywords : Self Reflection; Medical Students

\begin{abstract}
Abstrak: Perbedaan Tingkat Refleksi Diri Dalam Pembelajaran Mahasiswa Fakultas Kedokteran Universitas Malahayati Tahun 2019. Refleksi diri adalah bagian penting dari kegiatan, termasuk pembelajaran dalam pendidikan kedokteran. Mahasiswa Fakultas Kedokteran Universitas Malahayati harus mampu melakukan refleksi diri hingga dapat mengevaluasi setiap proses pembelajaran dan menentukan langkah apa yang harus dilakukan dalam menunjang keberhasilannya pada saat menempuh jenjang pendidikan pada tahap selanjutnya. Tujuan dari penelitian ini adalah mengetahui perbedaan tingkat refleksi diri dalam pembelajaran mahasiswa Fakultas Kedokteran Univesitas Malahayati angkatan 2015, 2016, 2017 dan 2018 pada tahun 2019. Jenis Penelitian ini adalah kuantitatif dengan survey deskriptif dengan menggunakan metode Accidental Sampling. Jumlah populasi adalah seluruh mahasiswa Fakultas Kedokteran Univesitas Malahayati angkatan 2015, 2016, 2017 dan 2018. Didapatkan sampel sebanyak 644 responden. Tingkat refleksi diri dalam pembelajaran mahasiswa Fakultas Kedokteran Univesitas Malahayati angkatan 2015 s.d 2018 pada tahun 2019 sebagian besar memiliki tingkat refleksi diri sedang sebanyak 363 responden (56,37\%), refleksi diri tinggi sebanyak 216 responden (33,54\%) dan refleksi diri rendah sebanyak 65 responden (10,09\%). Sebagian besar angkatan 2015 memiliki tingkat refleksi diri tinggi (64,56\%), sedangkan pada angkatan lainnya (2016, 2017 dan 2018) memiliki tingkat refleksi diri sedang. Terdapat beberapa perbedaan tingkat refleksi diri pada berbagai angkatan terutama angkatan 2015, namun sebagian besar tingkat refleksi diri dalam pembelajaran mahasiswa Fakultas Kedokteran Univesitas Malahayati angkatan 2015 s.d 2018 pada tahun 2019 memiliki tingkat refleksi diri sedang.
\end{abstract}

Kata Kunci : Refleksi Diri; Mahasiswa Fakultas Kedokteran 


\section{PENDAHULUAN}

Belajar dalam perspektif psikologi merupakan proses internal yang melibatkan 3 aspek yang meliputi ranah kognitif, afektif dan psikomotorik. Hal ini merupakan proses dasar dari perkembangan hidup manusia karena bukan sekadar menjadi pengalaman bagi setiap individu melaikan proses yang secara aktif dan integrative untuk encapai suatu tujuan perubahan perilaku (Nidawati, 2013). Seseorang yang menerapkan cara pembelajaran orang dewasa, memiliki kematangan konsep diri dan mampu mengukur perubahan perilaku yang terjadi untuk menjadi tolak ukur perencanaan dan pengembangan pembelajaran kedepannya (Sunhaji, 2013).

Mahasiswa Fakultas Kedokteran Universitas Malahayati dalam menghadapi kurikulum berbasis kompetensi diharapkan dapat menerapkan belajar tipe orang dewasa dalam pendekatan Problem Based Learning (PBL) sebagai model pembelajaran yang digunakan. PBL merupakan suatu pendekatan instruksional yang mengharapkan mahasiswa dapat menerapkan serta mengintegrasikan seluruh aspek teori dan praktek, pengetahuan dan keterampilan untuk menyusun solusi yang layak pada suatu masalah yang ditetapkan (Savery, 2006). Mahasiswa juga diharapkan dengan tipe pembelajar orang dewasa dapat mencapai kompetensi yang sesuai dan telah ditetapkan oleh Konsil Kedokteran Indonesia yaitu Standar Kompetensi Dokter Indonesia tahun (SKDI) 2012.

Salah satu area kompetensi SKDI adalah area profesionalisme dan mawas diri yang didalamnya mahasiswa diharapkan mampu mempraktikkan belajar sepanjang hayat dengan kinerja profesionalitas diri dan mengidentifikasi kebutuhan belajar untuk mengatasi kelemahan yang dimiliki. Refleksi diri dapat menjadi proses yang penting dalam kegiatan pembelajaran, karena mahasiswa dilatih untuk dapat melakukan evaluasi terhadap proses belajar, menilai pengalaman dan hal yang sudah dicapai, termasuk mengetahui kelemahan dan kekuatan dirinya, setelah itu kemudian menyusun suatu rencana perbaikan atau tindak lanjut yang sesuai. Hal ini jka sudah terlatih diharapkan akan menetap pada individu selama proses pendidikan hingga sepanjang hayat, yaitu terus menerus menjadi kebiasaan melakukan proses belajar sepanjang hayat disertai dengan refleksi diri (Oktaria, 2015).

Refleksi adalah proses kegiatan yang aktif, terus-menerus, gigih, dan mempertimbangkan dengan seksama tentang segala sesuatu yang dipercaya kebenarannya yang berkisar pada kesadaran siswa (Phan, 2008). Refleksi merupakan suatu bentuk respon pembelajar terhadap pengalaman, refleksi seringkali dipicu oleh 'missmatch' atau ketidakcocokan pengetahuan, keterampilan, atau attitude yang dimiliki dengan yang mereka alami saat hal tersebut terjadi atau disebut "experience of surprise" (Schon, 1983).

Selanjutnya proses refleksi memerlukan analisis kritis dan konstruktif terhadap pengalaman tersebut termasuk evaluasi terhadap perasaan dan pengetahuan. Fase selanjutnya adalah pembentukan perspektif baru terhadap situasi, atau hubungan individu dengan situasi tersebut ataupun membentuk struktur baru yang mendasari skema pengetahuan (Susani, 2009).

Refleksi dapat terbagi menjadi dua diantaranya reflection in action dan on action. Refleksi in action, yaitu refleksi yang dilakukan saat pengalaman itu terjadi, seperti merencanakan apa yang akan kita lakukan kedepannya saat kita menemukan kembali permasalahan yang sama. Sedangkan refleksi on action, yaitu refleksi yang dilakukan sesudah pengalaman tersebut terjadi, seperti melakukan tindakan atas apa yang telah kita rencanakan sebelumnya. Refleksi terdiri atas dua komponen besar, yaitu experience atau pengalaman dan aktifitas reflektif berdasarkan pengalaman yang terjadi. Experience merupakan respon total seseorang terhadap situasi atau kejadian, dalam hal ini yang meliputi adalah apa yang dipikirkan, dirasakan, dilakukan dan disimpulkan saat itu juga atau beberapa saat setelah pengalaman itu sendiri. Setelah experience terjadilah fase memproses yang disebut refleksi (Schon,1983). 


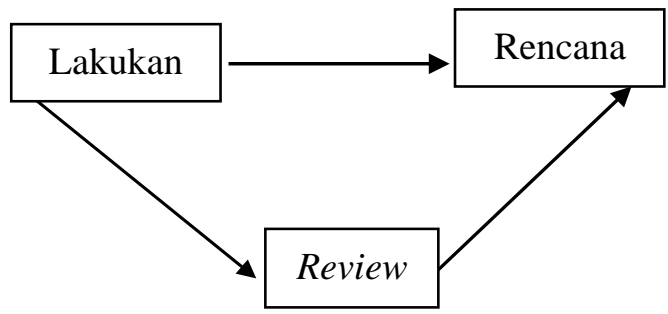

Gambar 1. Proses refleksi (Sumber: Sandars, 2009)

Refleksi merupakan aktivitas manusia untuk menangkap kembali pengalamannya, memikirkannya, dan mengevaluasinya. Proses ini harus dilakukan dalam keadaan sadar atau conscious. Proses unconscious reflection sering terjadi secara alamiah, namun proses tersebut tidak fokus dan tidak sistematis, sehingga bukan suatu proses belajar yang efektif. Ide-ide atau pemikiran harus dibawa ke dalam kesadaran sehingga membuat pembelajar mampu mengevaluasi dan membangun pemahaman baru. Refleksi dalam konteks belajar merupakan aktivitas intelektual dan afektif seorang individu yang terlibat untuk mengeksplorasi pengalaman dalam rangka membentuk suatu pemahaman baru (Boud, 2013). Boud menambahkan suatu model refleksi yang terdiri atas beberapa tahap (Gambar dibawah ini).

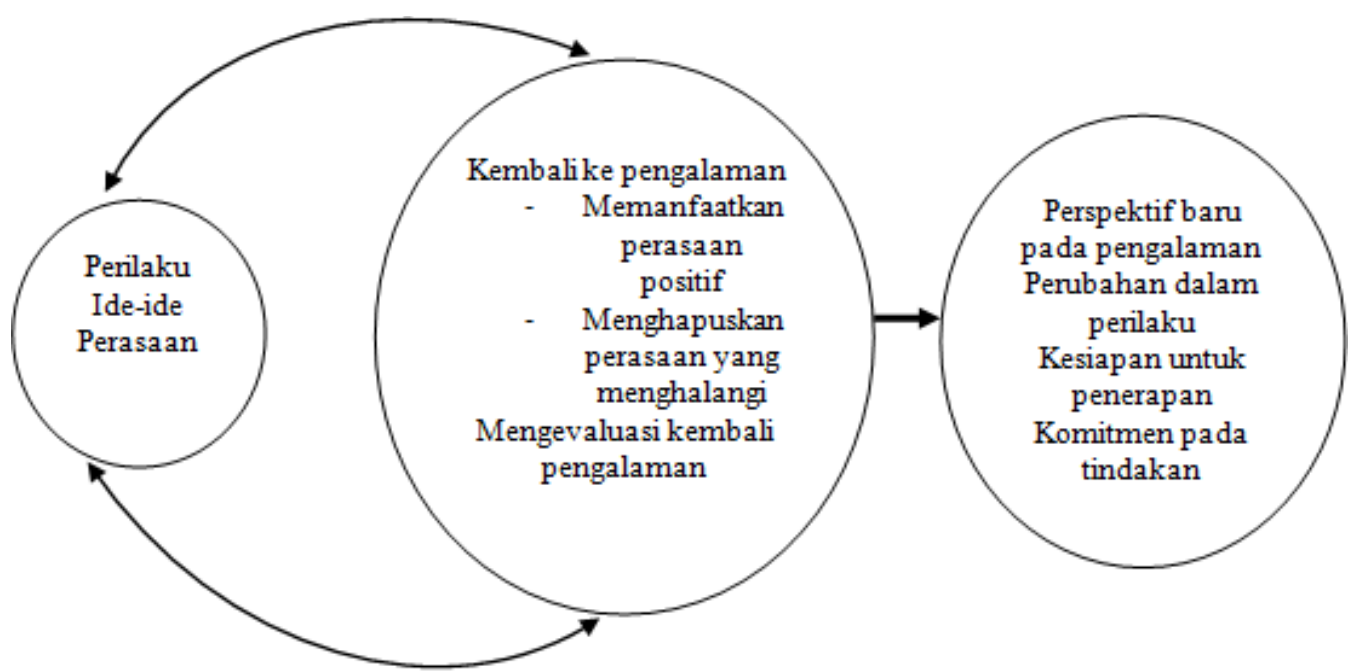

Pengalaman

Proses reflektif

Keluaran

\section{Gambar 2. Model refleksi (Sumber: Boud, 2013)}

Hasil dari proses refleksi ini dapat menentukan suatu cara baru bagi kita dalam melakukan suatu persoalan, mengklarifikasi suatu hal, perkembangan keterampilan, dan juga pemecahan masalah. Refleksi sendiri adalah suatu pengalaman yang bertujuan untuk $m$ embuat kita siap menghadapi pengalaman baru selanjutnya juga mereview hal-hal apa yang telah dilakukannya dalam suatu kegiatan, untuk menyusun rencana atau menggunakan pengalamannya tersebut pada kegiatan yang akan dating (Schon, 1983).

Refleksi dapat diukur dengan melakukan penilaian melalui kuesioner yang dimodifikasi dari kuesioner Metacognitive Awareness Inventory (MAI) (Schraw, 1994). Menurut teori David Boud
(2013) ada 3 tahapan yang akan diukur, meliputi:

1. Returning to experience

Proses refleksi dimulai dengan mengingat kembali, mengumpulkan data tentang pengalaman, atau memutar kembali pengalaman tersebut dalam pikiran. Akan lebih baik jika proses ini dijelaskan secara tertulis maupun secara lisan kepada orang lain.

2. Attending to feelings

Proses yang melibatkan perasaan yang terjadi dengan memaksimalkan perasaan positif dan membuang perasaan negatif sehingga membuat kita lebih fokus terhadap pengalaman tersebut. Perasaaan positif ini penting karena mendorong kita untuk bertahan dalam situasi yang sulit, membuat kita lebih tajam dalam melihat 
atau menganalisis sesuatu. Perasaan positif dapat ditingkatkan dengan mengingat kembali situasi ketika kita merasa baik, mampu, sukses dalam melakukan sesuatu.

\section{Re-evaluating experience}

Merupakan proses yang dapat dilakukan dengan melalui beberapa hal, yaitu proses asosiasi, yaitu mengkaitkan data baru dengan pengetahuan yang telah diketahui sebelumnya. Proses integrasi, melihat hubungan antar data. Proses validasi, yaitu menentukan otentisitas dan kebenaran ide atau pemikiran yang dihasilkan. Proses appropriation, atau penyesuaian yang membuat pengetahuan tersebut menjadi pengetahuan yang ditanamkan dalam pikiran kita.

Mahasiswa Fakultas Kedokteran Universitas Malahayati menempuh proses pendidikan yang sangat panjang mulai dari tahap sarjana hingga program profesi pendidikan dokter, oleh karena itu harus memiliki kemampuan melakukan refleksi diri. Harapannya setelah mahasiswa mampu mengetahui pentingnya refleksi diri, mahasiswa mampu mengatur diri dan menentukan langkah apa yang harus dilakukan dalam menunjang keberhasilannya pada saat menempuh jenjang pendidikan profesi dokter nanti.

\section{METODE}

Jenis Penelitian ini adalah penelitian kuantitatif dengan desain deskriptif dan pendekatan cross sectional. Sumber data dalam penelitian ini adalah data primer yang diambil dari kuesioner refleksi diri yang disusun dari modifikasi kuesioner Metacognitive Awareness Inventory (MAI).

Populasi pada penelitian ini adalah seluruh mahasiswa Fakultas Kedokteran Universitas Malahayati angkatan 2015 s.d
2018. Jumlah sampel pada penelitian ini diambil dengan rumus slovin sesuai dengan kriteria inklusi yaitu mahasiswa Fakultas Kedokteran Universitas Malahayati angkatan 2015 s.d 2018 yang bersedia menjadi sampel dan menandatangani Informed Consent. Teknik pengambilan sampel dilakukan dengan metode Accidental Sampling. Penelitian ini dilakukan selama April-September 2019.

\section{HASIL}

Berdasarkan hasil penelitian tingkat refleksi diri dalam pembelajaran mahasiswa Fakultas Kedokteran Universitas Malahayati angkatan 2015 s.d 2018 tahun 2019 diperoleh hasil sebagai berikut.

Karakteristik Jenis Kelamin Responden

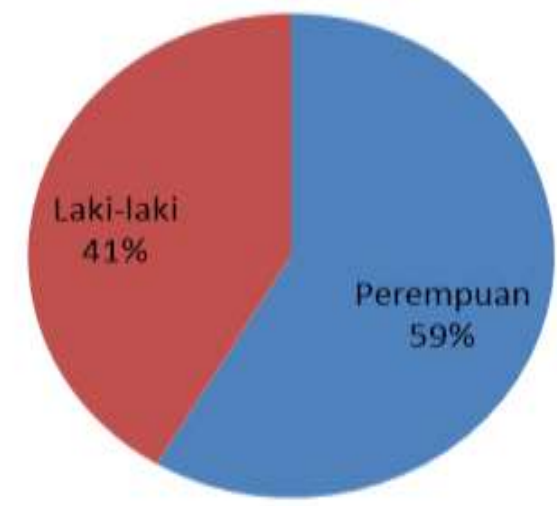

\section{Gambar 3. Karakteristik Jenis Kelamin}

Berdasarkan gambar diatas dapat terlihatdari total responden, sebagian besar adalah perempuan sebanyak 377 $(59 \%)$.

\section{Tabel 1. Distribusi Frekuensi Tingkat Refleksi Diri}

\begin{tabular}{cccccccc}
\hline Angkatan & $\begin{array}{c}\text { Tingkat } \\
\text { Refleksi } \\
\text { Tinggi }\end{array}$ & $\%$ & $\begin{array}{c}\text { Tingkat } \\
\text { Refleksi } \\
\text { Sedang }\end{array}$ & $\%$ & $\begin{array}{c}\text { Tingkat } \\
\text { Refleksi } \\
\text { Rendah }\end{array}$ & $\%$ & $\begin{array}{c}\text { Jumlah } \\
\text { responden }\end{array}$ \\
\hline 2015 & $\mathbf{1 0 2}$ & $\mathbf{6 4 . 5 6}$ & 55 & 34.81 & 1 & 0.63 & 158 \\
2016 & 32 & 17.58 & $\mathbf{1 2 3}$ & $\mathbf{6 7 . 5 8}$ & 27 & 14.84 & 182 \\
2017 & 36 & 20.22 & $\mathbf{1 2 8}$ & $\mathbf{7 1 . 9 1}$ & 14 & 7.87 & 178 \\
2018 & 46 & 36.51 & $\mathbf{5 7}$ & $\mathbf{4 5 . 2 4}$ & 23 & 18.25 & 126 \\
\hline Total & 216 & 33.54 & $\mathbf{3 6 3}$ & $\mathbf{5 6 . 3 7}$ & 65 & 10.09 & 644 \\
\hline
\end{tabular}


Berdasarkan tabel diatas distribusi frekuensi tingkat refleksi diri mahasiswa Fakultas Kedokteran Universitas Malahayati angkatan 2015 s.d 2018 didapatkan sebagian besar memiliki tingkat refleksi diri sedang yaitu sebesar 363 responden (56,37\%). Beberapa perbedaan tingkat refleksi diri tampak pada tabel, sebagian besar memiliki tingkat refleksi diri sedang, yang berbeda hanya terdapat pada angkatan 2015, yaitu sebagian besar memiliki tingkat refleksi diri tinggi sebanyak 102 responden $(64,6 \%)$.

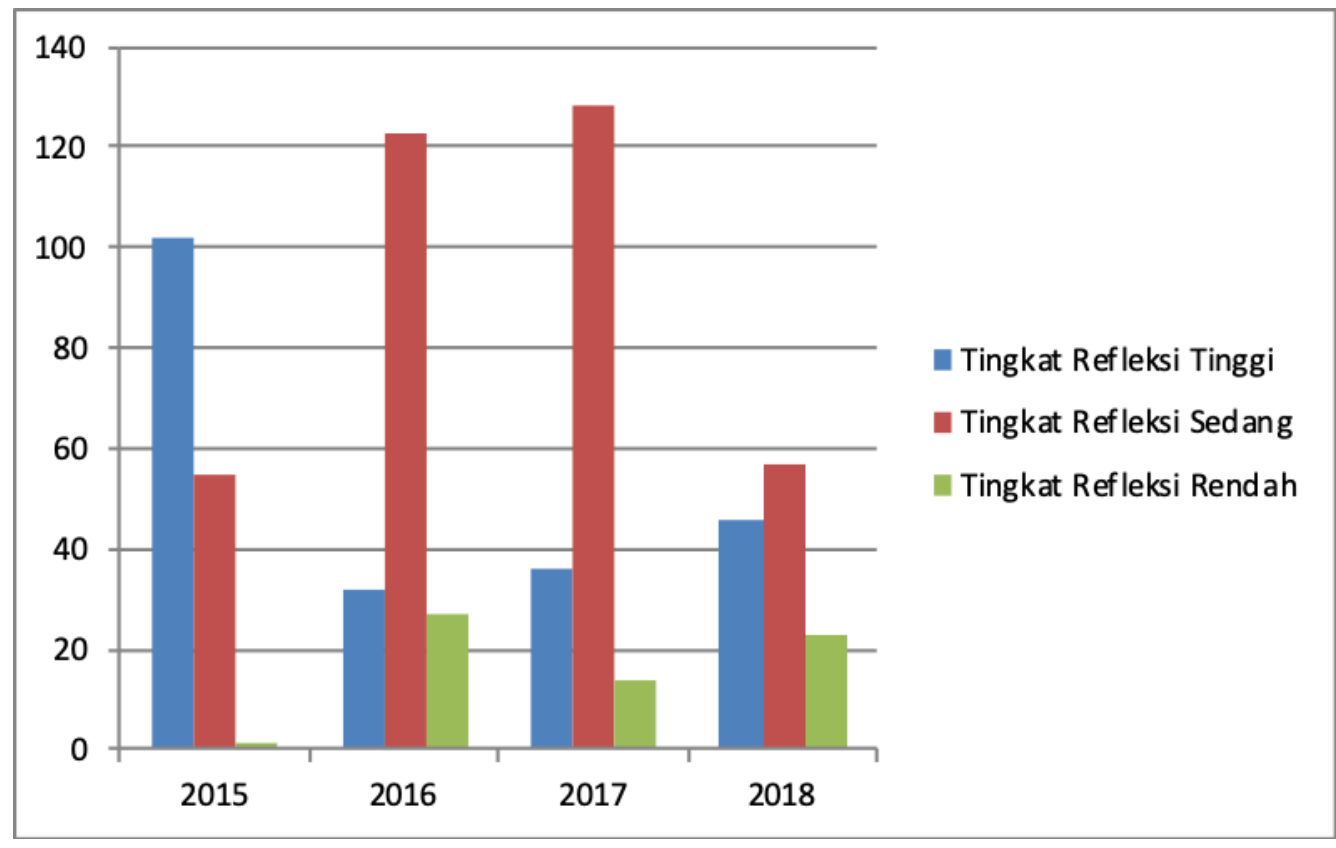

\section{Gambar 4. Grafik Perbedaan Tingkat Refleksi Diri Mahasiswa FK 2015, 2016, 2017, 2018}

Berdasarkan gambar grafik diatas tampak perbedaan dari tiap angkatan, sebagian besar semua angkatan memiliki tingkat refleksi diri kategori sedang.

\section{PEMBAHASAN}

Berdasarkan data yang diperoleh dari penelitian yang dilakukan pada bulan April-September 2019 di Fakultas Kedokteran Universitas Malahayati maka hasil penelitian ini dapat dibahas sebagai berikut.

Dapat dilihat pada gambar karakteristik jenis kelamin responden penelitian didapatkan dari 644 responden berdasarkan jenis kelamin yang tertinggi yaitu perempuan sebanyak 377 responden (59\%) lebih banyak dibandingkan laki-laki sebanyak 267 responden (41\%). Hasil penelitian ini sejalan dengan beberapa penelitian yang menunjukkan hasil bahwa perempuan lebih banyak dari pada jumlah laki-laki salahsatunya penelitia Imelda tahun 2018. Jumlah mahasiswa perempuan lebih banyak karena jumlah mahasiswa perempuan lebih banyak ditambah lagi sebagian besar yang bersedia berparti sipasi lebih banyak perempuan (Ritunga, Rahayu \& Suhoyo, 2018).

Berdasarkan tabel distribusi frekuensi dan persentase dari tingkat refleksi diri dalam pembelajaran mahasiswa fakultas kedokteran universitas Malahayati, data menunjukkan sebagian besar mahasiswa memiliki tingkat refleksi diri sedang sebanyak 363 responden $(56.37 \%)$, diikuti selanjutnya tingkat refleksi diri tinggi sebanyak 216 responden $(33.54 \%)$ dan terakhir yang paling sedikit memiliki tingkat refleksi diri rendah sebanyak 65 responden $(10.09 \%)$. Hal ini menunjukkan hal yang sudah cukup baik, bahwa kemampuan tingkat refleksi diri mahasiswa Fakultas Kedokteran Universitas Malahayati sebagian besar memiliki tingkat refleksi diri sedang dalam arti beberapa proses kegiatan refleksi diri dalam pembelajaran sudah mulai diterapkan, walaupun mungkin perlu 
adanya evaluasi dan upaya untuk meni ngkatkan lagi sehingga dapat menjadi tingakt refleksi diri yang tinggi. Westberg pada tahun 2001 menjelaskan suatu teori bahwa pembelajaran refleksi memungkinkan mahasiswa untuk mengidentifikasi dan membangun pengetahuan mereka sendiri serta membuat generalisasi dari pengalaman tertentu yang akan membantu mereka untuk mengaplikasikan pembelajaran dalam situasi selanjutnya. Selain itu, juga memungkinkan mahasiswa untuk mengintegrasikan pemahaman baru mereka (Westberg, 2001).

Mahasiswa Fakultas Kedokteran Universitas Malahayati yang menjadi responden adalah mahasiswa yang sedang menjalani proses pendidikan kedokteran tahap sarjana (preklinik). Sejalan dengan penelitian Oktaria pada tahun 2015 menyebutkan konsep pengajaran dan pembelajaran melalui refleksi diri perlu diintegrasikan pada pendidikan tahap preklinik secara lebih luas. Mahasiswa perlu dibekali dengan konsep yang jelas mengenai refleksi diri dan manfaatnya serta diberikan panduan dan aturan dalam melakukan proses refleksi diri. Melalui proses pembelajaran refleksi diri, diharapkan mahasiswa dapat menjadi pembelajar sepanjang hayat yang reflektif (Oktaria, 2015). Oleh karena itu sesuai dengan hasil penelitian, karena masih terdapat tingkat refleksi diri yang rendah perlu menjadi evalusai terkait pemaparan teori refleksi diri pada mahasiswa tahap sarjana dan evaluasi untuk penerapannya, hingga mahasiswa dapat memahami apa itu refleksi diri, pentingnya dan dapat terbiasa menerapkan disepanjang proses pendidikannya. Mahasiswa harus senantiasa meningkatkan pemahaman dan kemampuan refleksi diri dalam setiap kegiatan pembelajaran pada diri sendiri untuk persiapan menempuh langkah selanjutnya yaitu pendidikan profesi dokter.

\section{KESIMPULAN}

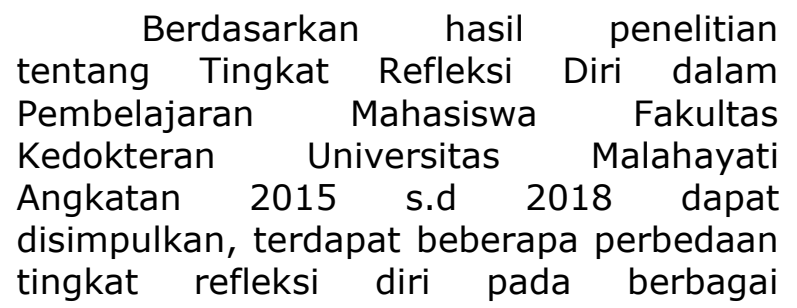

angkatan terutama angkatan 2015, namun sebagian besar tingkat refleksi diri dalam pembelajaran mahasiswa Fakultas Kedokteran Univesitas Malahayati angkatan 2015 s.d 2018 pada tahun 2019 memiliki tingkat refleksi diri sedang.

\section{DAFTAR PUSTAKA}

Boud, D., Keogh, R., \& Walker, D. (2013). Reflection: Turning experience into learning. London: Routledge.

Nidawati, N. (2013). Belajar Dalam Perspektif Psikologi Dan Agama. PIONIR: Jurnal Pendidikan, 4(1).

Oktaria, D (2015). Refleksi Diri sebagai Salah Satu Metode Pembelajaran di Fakultas Kedokteran. Prosiding Seminar Presentasi Artikel Ilmiah Dies Natalis FK Unila ke 13, 76-82.

Phan, H. P. (2008). Achievement goals, the classroom environment, and reflective thinking: A conceptual framework. Electronic Journal of Research in Educational Psychology. ISSN. 1696-2095. No. 16, 6(3), 571-602.

Ritunga, I., Rahayu, G. R., \& Suhoyo, Y. (2018). Critical Reflection and Feedback for Medical Students: A Comparative Study. Jurnal Pendidikan Kedokteran Indonesia The Indonesian Journal of Medical Education, 7(1), 74-82.

Sandars, J. (2009). The use of reflection in medical education: AMEE Guide No. 44. Medical teacher, 31(8), 685695.

Savery, J. R. (2006). Overview of problembased learning: definition and distinctions, the interdisciplinary. In Journal of Problem-based learning, 1(1), 9-20.

Schon, D. A., \& DeSanctis, V. (1983). The reflective practitioner: How professionals think in action. London: Routledge, 384.

Schraw, G., \& Dennison, R. S. (1994). Assessing metacognitive awareness. Contemporary educational psychology, 19(4), 460475.

Sunhaji, S. (2013). Konsep Pendidikan Orang Dewasa. Jurnal Kependidikan, 1(1), 1-11. 
Westberg, J. (2001). Helping learners become reflective practitioners. Education for Health-AbingdonCarfax Publishing Limited-, 14(2), 313-322. 